\title{
Diasporas and conflicts - understanding the nexus
}

\section{Élise Féron \& Bruno Lefort}

To cite this article: Élise Féron \& Bruno Lefort (2019) Diasporas and conflicts - understanding the nexus, Diaspora Studies, 12:1, 34-51, DOI: 10.1080/09739572.2018.1538687

To link to this article: https://doi.org/10.1080/09739572.2018.1538687

\section{(C) 2018 The Author(s). Published by Informa UK Limited, trading as Taylor \& Francis Group

Published online: 25 Oct 2018. \\ Submit your article to this journal}

\section{Џll Article views: 125}

View Crossmark data ‘ 


\title{
Diasporas and conflicts - understanding the nexus
}

\author{
Élise Féron and Bruno Lefort
}

Faculty of Social Sciences, Tampere Peace Research Institute, University of Tampere, Tampere, Finland

\begin{abstract}
A lot of literature has been published during the past two decades highlighting the role played by some diasporas in the conflicts raging in their home countries, and on the links between diasporas and 'international terrorism'. Diasporas, especially those originating from conflict areas, are often depicted in policy circles as potential security threats, raising indiscriminate suspicion towards diasporas in general. Contemporary literature similarly treats the links between diasporas and conflicts in a rather simplistic way. Little time is for instance dedicated to understanding how diasporas might emerge and coalesce around conflicts long after the migration has occurred. The article, based on a critical examination of how diasporas originating from conflict areas have been described and defined in the academic literature, proposes an alternative understanding of the nexus between diasporas and conflicts. It notably highlights the limitations and pitfalls of an approach based on single-issue labels, which entails the essentialization of concerned groups, and which perpetuates methodological nationalism. The article instead proposes to understand the mechanisms by which diasporas become involved in conflicts by looking at a series of configurations, which can happen at specific temporalities (critical junctures, crises, etc.), in specific spaces, by specific actors, and through specific discursive articulations (how identities are assigned, which discourses on diaspora are produced, etc.). At the practical level, this entails the study, for instance, of contentious spaces where diasporas are created, or which diasporas create, but also of contentious events or time junctures at which the articulation between conflicts and diaspora groups is effected.
\end{abstract}

ARTICLE HISTORY

Received 18 April 2018

Accepted 1 October 2018

\section{KEYWORDS}

Diasporas; conflicts;

securitization;

methodological nationalism

\section{Introduction}

A lot of literature has been published during the past two decades highlighting the role played by some diasporas in the conflicts raging in their home countries, and on the links between diasporas and international terrorism'. The study of the relations between diasporas and conflicts often follows a securitization trope which notably puts the stress on major financial flows that transit, sometimes illegally, from countries of settlement to conflict areas, and that fund rebel movements, combatants, ammunitions,

CONTACT Élise Féron Elise.Feron@uta.fi Faculty of Social Sciences, Tampere Peace Research Institute, University of Tampere, Tampere 33014, Finland

(c) 2018 The Author(s). Published by Informa UK Limited, trading as Taylor \& Francis Group

This is an Open Access article distributed under the terms of the Creative Commons Attribution-NonCommercial-NoDerivatives License (http://creativecommons.org/licenses/by-nc-nd/4.0/), which permits non-commercial re-use, distribution, and reproduction in any medium, provided the original work is properly cited, and is not altered, transformed, or built upon in any way. 
and so on (among many others, Collier and Hoeffler 2000; Horst 2008; Lyons 2007; Shain and Barth 2003). Diaspora groups originating from conflict areas are also suspected of 'importing' these conflicts in their countries of residence, and of organizing destabilizing activities through transnational underground networks. In these discourses, diasporas coming from conflict zones are depicted as potential security threats, raising indiscriminate suspicion towards entire communities (Sheffer 1994). From the dangers of terrorism to the risks to indigenous cultural cohesion and traditions, along with images of imported conflicts, diasporas have been securitized politically and culturally. This securitization trope is notably fed by, and feeds into, xenophobic discourses about migrants, in Europe and elsewhere (Lucassen 2005).

Diasporas' securitization is also partly due to a narrow understanding of who these diaspora communities are, and of how they mobilize. Attention is focused on diasporas from developing countries, while diasporas from developed Western counties are rarely regarded as being problematic or destabilizing, or as carrying the same level of threat as those originating from non-Western societies, even though they also engage in homeland-oriented political action. Further, these narratives often focus upon relatively small elements within diaspora communities, which are sometimes taken to epitomize a substantially broader spectrum of opinion. Narratives on the most visible, organized and mobilized sections of diaspora groups thus tend to obscure more discrete diaspora groups and overshadow diverse types of mobilization.

In parallel, other studies have shown that a significant number of diaspora actors participate in peace building and in conflict resolution activities in their countries of origin as well (Smith and Stares 2007; Østergaard-Nielsen 2006). Diasporas originating from conflict areas have also been shown to participate in post-conflict stabilization and development plans, and multiple policy schemes have been set up to harness their good will (Féron 2014; Horst et al. 2010). In certain cases such as the one of the Irish Americans, diasporas' backing 'for peace' has been much more significant than their contributions to conflict activities 'back home', but has attracted much less media, policy and academic attention (Cochrane, Baser, and Swain 2009).

All in all, whether it is to highlight their constructive or destructive impact on conflicts in their countries of origin, or their involvement in 'international terrorism', diasporas originating from conflict areas are typically depicted as potential peacemakers and/or peace wreckers. These two complementary approaches, which share a focus on the direct ways diaspora groups impact the dynamics of peace and war in their homelands, have been dominant in the literature at the expense of more nuanced explorations of the complex links existing between diasporic communities and conflicts. Little time is for instance dedicated to comprehend how conflicts might affect diasporas, and even shape them, or why diasporas can become involved in conflicts happening in countries from which they do not originate. This limited understanding of the diaspora-conflict nexus, this article argues, notably derives from the tendency to assign homogeneous and stable identities to diaspora groups, which are mostly defined by their (assumed or real) origins.

In this perspective, the article critically examines existing definitions of the concept of diaspora, and provides an overview of how diasporas originating from conflict areas have been described and defined in the academic literature. In doing so, it intends to contribute to a revised, more complex understanding of the diaspora-conflict nexus, freed from the shortcomings of the peace-makers/peace-wreckers alternative, and thus to provide 
avenues for research and policy making towards de-securitized, fluidified visions of diasporas. The article lays down this central contribution in the following manner. First, it shows how existing concepts and approaches ultimately fail to describe and capture the complexity of relations and interactions stemming from the diaspora-conflict nexus. It then discusses the methodological and epistemological limits of these approaches, and argues that they ultimately lead to an analytical impasse. It notably highlights the pitfalls of an approach based on single-issue labels, which entails the essentialization of concerned groups, and which perpetuates methodological nationalism. Instead, the article proposes to understand the diasporas-conflict nexus as a series of configurations, in which actors such as diasporas themselves, institutions or individuals in countries of origin or in countries of settlement, as well as transnational actors, can all play a decisive role. At the practical level, this entails the study, for instance, of contentious spaces where diasporas are created, or which diasporas create, but also of contentious events or time junctures at which the articulation between conflicts and diaspora groups is effected.

\section{Acknowledging the complexity of the diaspora-conflict nexus}

Originally referring to the dispersion of Jewish people, the word 'diaspora' has gained considerable currency to the point that ' $\mathrm{i}$ ] n everyday language, the term is now applied to all forms of migration and dispersion of a people' (Bruneau 2010, 35). Similarly, since the end of the 1980s, the notion has generated multiple definitions and endless debates within the academic world. While some have insisted on a definition of diaspora grounded on the existence of a voluntary or involuntary dispersion from a mythicized homeland, nourishing a troubled relationship with the country of settlement (see e.g. Safran 1991, 83-84), other have underscored the importance of processes of collective identification and mobilization, 'through a developed internal organizational framework and transnational links' (Adamson and Demetriou 2007, 497). According to Pnina Werbner (2002, 121) 'Diasporas need to be grasped as deterritorialised imagined communities which conceive of themselves, despite their dispersal, as sharing a collective past and common destiny, and hence also a simultaneity in time'. Diasporas, she adds, are 'chaordic' (123), without a common guiding structure, yet it remains important to recognize that they are still somehow attached to their countries of origin and/or to specific myths and memories about that place. Diaspora is also to be understood as a performative concept: naming a group diaspora erases the notion of dispersion at the heart of the diasporic form and makes it appear as a single object (Ma Mung 2007, 413). In an attempt to provide an overall definition, Steven Vertovec (1997) argues that the concept of diaspora refers at the same time to a social form created by the scattering, displacement of a population, a form of social identification, and a mode of cultural expression. The multiplication of these discussions about the nature of diasporas has led to a considerable degree of concept stretching, and to great confusion as to what diasporas are (Brubaker 2005). Yet, ultimately, the strength of the notion is less to describe one reality than its ability to question the polymorphism of contemporary societies (Ma Mung 2007, 412413). Precisely because of its ability to question the complexity of human societies, the notion of diaspora remains useful. The multiple uses of the notion do not impede its efficiency, on the contrary, they enable to always renew our exploration of social forms (415). 
Ultimately, complexity lies at the heart of the notion of diaspora. This complexity refers at the same time to the distinction between various forms of spatial dispersions and transnational communities, but also to the pluralism prevailing in each of them, i.e. their internal complexity. Before introducing the diversity of forms that diasporic communities may take, it is important to note the distinction between diaspora and transnationalism, two concepts that are at the centre of contemporary academic and public discussions (Baubök and Faist 2010, 12). While they originate in spatial mobility across territories, diasporas only constitute one type of transnational communities among others, which includes various migration, transborder or nomadic movements. Indeed, if 'transnational communities encompass diasporas (...) not all transnational communities are diasporas' (21). Beyond this necessary distinction with transnational populations, diasporic communities also present a multiplicity of forms. Spatially, it is possible to differentiate between contiguous and distant diasporas. The former are constituted by populations spread between neighboring countries whereas the latter, as their name indicate, result from more distant settlement. Obviously, the diasporic experiences of these communities relate to distinctive realities. Moreover, some diasporas are dispersed in a multitude of countries while others are concentrated in one or few places of settlement. Diasporas also differ in their histories and organizational structures. Drawing on these variations, Michel Bruneau (2010, 39-40) sketches four ideal types of diasporic communities, depending on their construction around an entrepreneur pole (with the examples of the Indians, Chinese or Lebanese diasporas), a religious pole (e.g. Jewish, Greek or Armenian diasporas), a political pole (e.g. the Palestinian diaspora) or a racial-cultural pole (e.g. the Black diaspora).

Aside from these formal and historical variations, all diasporas also present a high degree of internal complexity. Beyond the differences between diasporas, the plurality existing among each of them has also to be acknowledged. Indeed, it is obvious that no diaspora is homogeneous, to the point that it appears often misleading to designate them as ' $a$ ' group. The cases of fragmented communities along sectarian or ethnic lines provide a strong illustration of this complexity (e.g. Rwandan diaspora divided between Hutus and Tutsis, etc.). The multiple generational layers that gradually composed diaspora groups have also to be taken into account, all the more since these successive waves might have been generated by different causes. Moreover, the spatial and temporal contexts play a key part in the construction of diasporic communities. The moment of the immigration as well as the configurations of the host societies both induce some differences in the experiences of diasporic groups even if they originate from the same homeland (e.g. Humphrey $(1998,136)$ suggests that sectarian boundaries among the Lebanese diaspora of the 1980s appear more salient in Australia than in South America). Also, the main reason given for migration might 'hide' other factors, for instance 'conflict' veiling religious or ethnic factors, which may be as, or even more important, for these groups. Finally, diasporas are not created automatically, their constitution is dependent upon specific events or processes. The case of the Ottoman diaspora groups 'becoming' Palestinians, Lebanese or Syrians following the dismantlement of the Ottoman Empire and the conflicts that followed provides a clear illustration of this complex interdependency between diaspora and political processes.

Because of the complex nature of diasporas, their definition yields serious difficulties. These complications further increase when one wants to study the links between diasporas 
and conflicts. As diasporic groups are multiple and internally heterogeneous, conflicts are likewise intricate processes that can be distinguished according to their types, stages or dimensions. The interrelations between conflict configurations and the formation or mobilization of diasporas are therefore multifaceted. The commonplace idea of conflict as the cause of diaspora formation and a shared heritage (at least in terms of transmitted memory) among a specific diasporic group does certainly not capture the plural realities of diaspora experiences. Among the concepts crafted to understand the links between diasporic groups and conflict, the classic idea of 'victim diaspora' emerges in the first efforts to popularize diaspora studies. This notion does not make justice to the multiplicity of linkages between migration and violence. It excludes for instance the possibility that those who have fled their country and established abroad might not be only 'victims' but also count among them perpetrators of violence as the example of Hutus war criminals leaving Rwanda after the genocide illustrates. Besides, the idea of 'victim diaspora' theoretically also includes victims of non conflict-related events such as natural disasters.

In the last 30 years or so, two main concepts striving to capture the links between diaspora and conflict have emerged. The first notion, coined 'ethno-national diasporas' by Sheffer, remains very broad. According to him, 'modern ethno-national diasporas are social and political entities that arise from migration (which may be voluntary or imposed and usually from an ethno-national state or homeland) to one or more host countries'. Based on this definition, Sheffer argues that all diasporas have a potential for conflict. 'Diasporas often create trans-state networks that permit and encourage exchanges of significant resources, such as money, manpower, political support and cultural influence, with their homelands as well as with other parts of the same diaspora. This creates a potential for conflict with both homelands and host countries, which, in turn, is linked with highly complex patterns of divided and dual authority and loyalty within diasporas' (Sheffer 1994, 61). However, the vagueness of the concept is such that it could include most, if not all, diaspora groups. It misleads to consider that diasporas are inherently conflictual. The confusion is fuelled by ideas of dual loyalty or long-distance nationalism, which remain unquestioned. Nothing is said for instance about the configurations in which dual loyalty may lead to conflict. In the light of these limitations, the concept of conflict-generated diasporas has emerged as a more recent alternative. It relates to 'networks of those forced across borders by conflict or repression' (Lyons 2007, 530). Although arguably more focused than Sheffer's 'ethno-national diaspora', the concept of conflict-generated diaspora is often taken for granted and seldom thoroughly defined in the existing literature. The limitations of the concept led to the adoption of a more nuanced approach by Maria Koinova et al. (2018) putting the stress on spatialities and temporalities of diaspora engagement, and demonstrating the co-construction patterns between diasporas and the context in which they mobilize. However, this approach does not explicitly question the concept of conflict-generated diasporas itself, leaving the full implications of the notion underexplored.

Located at the nexus between migration and peace and conflict studies, the concepts of ethno-national and conflict-generated diasporas try to account for both conditions in countries of origin, and context in countries of settlement. However very few empirical studies building on these concepts propose to account for both perspectives, and diaspora groups are often studied either from the perspective of integration in the countries of settlement, or from the perspective of the conflicts raging in their countries of origin 
(and then consider them as either peace wreckers or peace makers). Meanwhile, diasporas have become the focus of security and securitization studies, in the wake of Jihadi attacks in Western countries. Security discourses voiced by politicians, media and commentators alike have paid particular attention to the so-called 'Muslim Diaspora', assumed to carry a high potential for involvement in violent actions. According to these discourses, the 'Umma' replaces the homeland as a trigger for participation in conflicts. One of the paradoxes that these recent studies have highlighted is that diaspora members involved in conflicts are not always coming from war-torn areas, and that the conflicts they engage in are not necessarily occurring in their own countries of origin.

This calls to attention the fact that all of the definitions listed above assign static - and conflict-related - identities to diaspora groups, when the reality of their relations to conflict is much more complex. There is an urgent need to steer away from these definitions that focus on the group itself and to look at the configurations in which they might become involved in conflicts, and to pay more attention at how conflicts might shape them, regardless of where they come from.

\section{Approaching the diaspora-conflict nexus beyond reductionism}

Because its definitions tend to focus primarily on group identities, the concepts of ethno-national diasporas, or of conflict-generated diasporas raise ethical, methodological as well as analytical questions. First, like for all diaspora groups, the emphasis put on ethno-national identities entails ethical concerns. The choice of insisting on ascriptive identities tends to overlook the internal diversity and plurality among diaspora groups and highlights the reference to an 'original' or pure identity or culture that people could not escape. Moreover, the concepts of ethno-national or conflict-generated diasporas are specifically problematic as they suppose to define populations on the basis of the conflict they have fled. This suggests that they are (potential) conflict actors, and draws additional suspicion on them, overlooking the fact that in many instances, they might just have fled a conflict fought by others as well as the fact that the migration of all the members of a given diaspora labelled as 'conflict-generated' might not have been triggered by the conflict. Indeed, successive migration waves can be generated by a great variety of causes, as show the examples of the Lebanese or Armenian diasporas. The dominance of security discourses regarding diasporas in general and conflict-generated migration in particular tends to posit that their very existence generates a threat to the stability of their hostlands. Considering diaspora under the 'security threat' prism criminalizes entire groups, on the single basis that they belong to a given communal/religious/national background. These trends also echo the contemporary controversies on a supposed double allegiance of people or groups originating in another country. This vision endorses what could be called a hierarchy of identities, whereby people belonging to what have been identified as risk groups are being ordered to 'choose' and/or 'reassert' their loyalty to their hostland (as illustrated for instance in the public debates stigmatizing Muslims in France). Beside their xenophobic overtones, these discussions ignore the fact that not only everybody carries plural identities but also that these multiple facets operate more as an evolutive, interconnected arrangement than in a predefined hierarchical order.

This insistence on origins is also ethically problematic because, 
it anchors the work of the diasporan scholar in the observation of groups, rather than in the dynamic social processes of diasporization from which these groups are created. There is also a risk of moving towards essentializing "diaspora" as an ethnic label rather than a framework of analysis. (Butler 2001, 193)

In that perspective, the ascription and homogenization of people behind ethno-national labels of conflict-generated diaspora can be assimilated to a form of epistemological violence (Shiva 1988) whereby researchers exercise violence over their object as the 'Other' is interpreted according to reductionist perceptions that represent groups as homogeneous. Homogenization is, as Spivak reminds us, social and political control exercised by hegemonic voices (Spivak 1990, 61). The case of the Irish diaspora in the US is an interesting illustration of this tendency, since its protestant component, though making up the majority, is totally overlooked in representations assuming that 'Irish-America' is supporting the reunification of Ireland. Of course, this is not to mean that the notion of diaspora is itself a form of epistemological violence. But the definition of a group of people in terms of ascriptive identities as well as under the single qualification of conflict-generated is. Taking some distance vis-à-vis primary identity conflicts is all the more significant since diasporas not always dream to return to a potential homeland. This insistence on homeland origins and return is, according to Stuart Hall, a narrow-minded understanding of diasporas, suggesting that they belong to a 'genuine' culture to which they have to go back (1995, 206). On the contrary, diaspora 'aims to account for hybridity or performativity that troubles such notions of cultural dominance, location and identity' (Israel 2000, 3).

Second, these epistemological considerations highlight methodological shortcomings. The choice of emphasizing ascriptive identities, whether national, ethnic or religious, may well point toward the persistence, under a new outfit, of methodological nationalism. The term 'methodological nationalism' has been mostly discussed in the field of Migration Studies. It originally refers to 'an ideological orientation that approaches the study of social and historical processes as if they were contained within the borders of individual nationstate'. This tendency led to the assumption that citizens of a same state would share a mutual history and a same culture (Glick Schiller 2009, 4). While the transnational dimension of social processes has been more and more seriously integrated within social theory (e.g. Beck 2000; Hannerz 1996; Latour 2004), it remains that the analytical focus put on primary identities by the concept of conflict-generated diasporas tends to circumscribe the study of diaspora groups under a nationalist / ethnicist / sectarianist framework and makes explorative investigations beyond this framework more difficult. As Nina Glick Schiller $(2009,5)$ puts it, the tendency to,

bound (...) unit of study along the lines of national or ethnic identities (...) isolate[s] the analysis of migrant local and transborder connections both from explorations of the new flexible modes of capital accumulation and contemporary neoliberal restructuring of space, self, and society (...). The end result is that the unit of analysis - often described as a "transnational community" - becomes a migrating population defined and delimited by communal cultural identities.

This is all the more problematic that many members of diaspora groups originate from areas where national borders are fluid, and whose existence is shaped by transnationalism too, such as in the Great Lakes Region of Africa, or in the tribal areas of Afghanistan and Pakistan. Similarly, the dominant approach on diaspora groups is marked by essentialism 
(Ragazzi 2009, 383). Studies of 'conflict-generated diasporas' have privileged primary identities as units of analysis and have insisted on 'long-distance nationalism' (Anderson 1993), ethnic or communal cohesions as a way to explain the intervention of diaspora groups in homeland conflicts as well as the transposition of these conflicts to their homeland. This 'neo-communautarist' trend in transnational studies relies on a 'biological imaginary' (Glick Schiller 2005, 303), and reproduces the view of a world divided along bloodlines in cohesive national or cultural entities (Wimmer and Schiller 2002, 324). It also hampers the ability of analytical and conceptual tools to recognize the heterogeneity of diasporic groups as well as the plurality of the forces at work in local configurations with enough precision. In other words, there are multiple ways of belonging. Assuming communal solidarity and boundaries among diaspora members as well as between them and their homeland does not allow us to grasp the complexity and versatility of the interplay between diaspora groups and dynamics of peace and conflict. Such an approach also overlooks the numerous cases where there is not one but multiple versions of nationalism in the country of origin.

Methodologically, the problem also stems from the fact that most often, the concepts of ethno-national or conflict-generated diaspora suppose more than demonstrate the existence of contentious relations between diaspora groups, also called 'imported' or 'transported' conflicts. These conflicting dynamics are assumed to be based on the existence (or past existence) of conflict in homeland(s) without sufficient attention put on describing the empirical reality of these relations: the potential peace making vs. peace wrecking roles of diasporas have been much studied, but there are far less numerous detailed analyses of the actual consequences of conflict in hostland local contexts (Baser 2015, 8). Against the idea of a mechanical importation of conflicts, the notion of autonomization (Féron 2013) is of primary importance as it rightfully points toward the complexity of the links as well as the pivotal role of local configurations to understand the development of contentious or peaceful dynamics among diaspora groups (Baser 2015). If there is undoubtedly 'imported' elements in the extension of homeland conflicts in the hostlands, 'transported conflict between diaspora groups takes on different features and dimensions than it does in the country of origin' (Féron 2013, 71): transportation entails deep changes in the structures, dynamics and even narratives of the conflict. Displacement of conflict supposes its reinscription into 'another context with a different set of opportunities and limitations'. (Baser 2015, 256) The impact of displacement as well as the well-established idea that identities and cultural practices are constructed in interactions in local and relational settings highlight the methodological cul-de-sac of taking primary identities as the analytical starting point. Conflicts in the homeland are crucial to the existence of diasporas (Bauböck 2008 , 3), and as long as conflict will exist in the homeland, it will be felt by (and impact the formation of) communities abroad (Baser 2015, 268). However, it should not mislead us toward essentialist approaches.

Partly as a reaction against this risk of essentialization, the last decade has witnessed the emergence of a mobilization approach in diaspora studies (see e.g. Adamson 2012; Lyons 2007; Østergaard-Nielsen 2012). Defining diasporas as the result, not the cause of mobilizations (Adamson 2012, 26) this approach enables to shift the focus from primordial identities toward social and political dynamics. In that perspective, diasporas are the product of mobilizations inspired by political entrepreneurs. This social movement framework allows to pay attention to the processes of political mobilization that create diasporas 
in the public sphere, but it is not without risks. In particular, this approach may lead to a magnifying-glass effect Glick Schiller $(2013,29)$. notably warns against the 'ethnic association fetish'. She notes that these diaspora associations only gather a small number of migrant communities. Hence, centreing the analysis of transnational politics on their mobilization may give a distorted picture of these processes. Besides, these associations usually have an interest in claiming cultural or identity uniformity as a ground for a stronger political voice, as demonstrated by Canefe in the case of the Turkish-Cypriot diaspora $(2002,67-68)$. Further, if it is true that it is not the diaspora that creates the mobilization but the mobilization creates the diaspora, it seems difficult to limit diasporas to mobilizations. It is not our intention to suggest that the mobilization approach on diasporas is flawed. On the contrary. Its greatest merits are precisely to look away from an identity-based conception of diaspora to shift the focus toward social processes of mobilization (Adamson 2013, 67). Acknowledging this significant feature, we intend to develop avenues that would complement the mobilization approach on diaspora.

A third methodological problem often induced by the concepts of ethno-national and of conflict-generated diasporas is that they lead to an analytical impasse that can be summarized as a form of teleological fallacy. As it is the case when dealing with primary identities such as ethnic or sectarian divisions, there is a big risk that starting from these social forms of experiences leads to the overemphasis of these very notions in the result of the analysis. Admittedly, such notions have a strong social relevance in the life of many people. Yet, the fact that these forms are central to their experiences does not mean that they are an adequate concept to make sense of the social reality. This is the very distinction between category of practice and category of analysis put forward by Brubaker and Cooper (2000). Hence, using identities as the basis for analysis would only reinforce the impression of their centrality.

It seems more useful to shift the analytical emphasis out of ideas of ascriptive identities to rather document if, when and how the references to primary identities, communal bonds and boundaries resurface in situation. Even if it is clearly the case that so-called ethno-national or conflict-generated diasporas cannot be studied separately from the reference to a homeland and the politics of identity, the question rather lays in the analytical focus, which should prioritize the temporalities and spatialities of contentious dynamics among diaspora groups over notions of reproduction or importation of identity conflicts. Paradoxically, the question of space and location has long been relegated at the margins in the field of diaspora studies (Bayeh 2015, 2). Avtar Brah's $(1996,177)$ notion of 'diaspora space' precisely helps to resituate diaspora studies into a politics of intersected locations - at once physical locations as well as symbolic and discursive spaces. Diaspora is 'a double consciousness' (Dayal 1996, 58), a 'territorialized critical consciousness' (Bayeh 2015, 10). This supposes to go beyond the duality between homeland and hostland (Dayal 1996, 46) to focus on experiences marked by the ambiguities and vacillation between 'here and there' and 'now and then', i.e. spatial and temporal consciousness constitutive of the diaspora experience, which 'is not defined by essence or purity, but by the recognition of a necessary heterogeneity and diversity'. (Hall 1994, 401-402). Incorporating this multiplicity of spatial and temporal experiences are crucial in the case of 'contentious diaspora spaces' because local configurations are instrumental in the recomposition of antagonism (Féron 2013; Baser 2015) and temporal circumstances (like the moment of 
migration or its wider global context) deeply impact the formation of the diaspora (see e.g. Hepner 2009).

The acknowledgement that 'all diasporas are heterogeneous and we shall find ways to tackle that plurality' led to a 'postmodern turn' in diaspora studies (Knock and McLoughlin 2010, 11), highlighting 'hybridization' (Bhabha 1994), 'creolization' (Chivallon and Martin 2006, 342) and 'cosmopolitanism' (Hannerz 1996; Vertovec 2010) of societies more and more marked by the diasporic experience. These conceptions underline the complexity and constant evolution of identities and are thus intellectually stimulating but carry the risk of a dilution of the concept of diaspora itself. Studying the temporal and spatial contingencies and entanglements at the heart of the diasporaconflict nexus is a challenge. How to navigate these precarious routes? The concept of diaspora remains useful in particular in its ability to question the social fabric and articulate key couples such as the single and the multiple, order and disorder, diversity and unicity, identity and alterity, the individual and the collective (Ma Mung 2007, 409). Diasporas are polymorph forms, objects that point toward the imbrication of space, society and movement (413). Because diasporas present many aspects of the contemporary world, the strength of this notion hence derives from its capacity to question social constructs.

\section{Disentangling the diaspora-conflict nexus}

In order to avoid these various hurdles, we propose to move away from definitions depicting diasporas as generated and/or defined by conflict, trauma or ethno-national identities, and to understand the relations between diasporas and conflicts as configurations in which actors such as diasporas themselves, institutions or individuals in countries of origin or in countries of settlement, as well as transnational actors can all play a decisive role. In addition, multiple factors can prompt a conflict-related mobilization among diasporas, such as the politics of memory in the countries of origin and/or of migration, events or experiences in the countries of origin, in the countries of residence, or elsewhere, and so on. Mobilization can also be triggered by discourses pertaining to the diasporas' situation in the countries of residence, but also by discourses of solidarity and responsibility relative to communities in the countries of origin or elsewhere, which can themselves build on general cultural or religious elements, or on ideologies, etc. And, needless to say, all of this may not affect all members of diaspora communities in the same way, at the same time, and for the same length of time.

This approach entails to fully embrace the complexities of diaspora politics, such as the fact that conflicts can structure diasporas which themselves might not be conflict-generated, that some - and indeed, many - populations originating from conflict-countries do not display any interest in, or relation to, those conflicts, or that conflicts might shape diasporas long after they have migrated. Indeed, as captured by Demmers $(2007,8)$ with the concept of 'diasporic turn', specific events or developments happening in countries of origin can trigger diasporas' identification and mobilization, sometimes generations after migration has taken place. In other words, unpacking the conflict-diaspora nexus demands to question many assumptions of long-distance nationalism that often remain implicit, and to recognize that diasporas' mobilization is neither automatic nor necessarily triggered by events in the countries of origin or of residence. 


\section{Toward a configurational analysis of the diaspora-conflict nexus}

Departing from a narrow view focusing first and foremost on the causal relation [conflicts $=>$ conflict-generated diasporas $=>$ conflicts] allows us to acknowledge that the conflictdiaspora nexus actually pertains to a great diversity of configurations, among which eight seem to stand out:

The first configuration relates to a scenario that has been the focus of numerous studies and in which some diaspora sections are indeed 'conflict-generated' or 'conflict-induced'. Obvious examples include Armenians who fled the genocide in 1915, or Tutsi and moderate Hutu who escaped Rwanda in 1994. That such conflict-generated diaspora waves take place in no way means that these individuals' existence is solely shaped by conflicts in home countries, and/or that they wish to become involved in their resolution or perpetuation - many members of diaspora groups would rather forget the reasons that pushed them or their forebears into exile. It also does not entail that the diaspora as a whole, say, the Armenian diaspora, is 'conflict-generated'. Similarly, the internal diversity of all diasporas has to be taken seriously; there are, for instance, very few studies comparing conflict-generated diaspora sections to others, say, the Lebanese who have fled the civil war in Lebanon, and those who have left before, for trade or other economic reasons.

Second, and this has also been well studied, parts of a diaspora and/or some diaspora actors, can be peace makers or peace wreckers, sometimes both at the same time (Smith and Stares 2007; Østergaard-Nielsen 2006). Instead of being shaped by a given conflict, these groups become preeminent conflict actors, such as currently in Burundi, where diaspora groups, particularly those settled in Belgium, embody the opposition to the Burundian government. To put it even more clearly, this not only means that home conflicts can be rejuvenated and reactivated, but also solved and terminated, through diaspora involvement. Existing literature has also shown how diaspora roles can evolve with time, as exemplified with the Croatian diaspora, which both funded armed conflict during the break-up of Yugoslavia and, in the later conflict stages, was active in support for peacebuilding (Baser and Swain 2008). Yet, beyond empirical data derived from specific case studies, little is known on what triggers diaspora groups' support for peace, or for continuation of the conflict.

Third, the conflict-diaspora nexus also pertains to the fact that conflicts occurring in countries of origin can be transported to countries of settlement through diaspora practices, through instrumentalizations by countries of origin, and/or through other transnational events or actors. Conflict-generated diaspora sections can carry on fighting in their countries of residence, or conflicts occurring in countries of origin can trigger clashes between diaspora groups that were not necessarily conflict-generated, as shown for instance by the numerous verbal and physical clashes between Kurds and Turks settled in Europe (Baser 2015). Here again, it is important to understand that conflict transportation is not necessarily the direct continuation of a conflict which would have led to migration, but that conflicts 'back home' can trigger tensions between non- (or partially) conflict-generated diaspora groups.

Directly following up from this, several well documented cases, such as the Sikh and the Kashmiri ones, suggest that conflicts raging in home countries can also literally call diasporas into existence long after migration has taken place, by indexing their identification and mobilization towards their countries of origin. For instance, the insurgency of 1989 in 
Kashmir led many Muslims originating from Azad Kashmir (Pakistan-administered part of Kashmir) to identify as part of the Kashmiri diaspora. Similarly, Sikh diaspora groups started to coalesce and mobilize after the Indian Army's intervention against the Golden Temple in Amritsar in 1984 (Moliner 2007). Largely similar processes were at play among members of the Kurdish diaspora after the coup in Turkey in 1980 (Van Bruinessen 1998).

Fifth, there is ample empirical evidence that transported conflicts in diaspora settings can and indeed often autonomize themselves from conflicts occurring in countries of origin, and become significantly different in shape and in issues, therefore giving birth to a new conflict cycle (Féron 2017). As a consequence, analyzing conflicts occurring in diaspora settings as if they were always a simple reproduction of conflicts raging in home countries is not just analytically wrong, it also impedes our ability to come up with appropriate approaches and solutions. In addition, the fact that diasporas often have different views on conflicts 'back home' than communities in the countries of origin, may create tensions between them. Diasporas' involvement in their home countries is not always seen as positive, especially when this involvement is likely to question existing political balances, as has been already shown in the Armenian case (Koinova 2011). Suspicions of 'neo-colonialism', especially in the developing world when diaspora groups adopt what is seen as western values and discourses, and/or when they work hand in hand with western-based organizations, also stand in the way of diasporas' involvement.

Sixth, there is scattered empirical evidence suggesting that diasporas' mobilization with regards to conflicts can be triggered horizontally, between diaspora groups themselves, and without the direct involvement of either countries of origin or countries of residence. In September 2015 for instance, severe clashes between the Kurdish and the Turkish diasporas that had occurred in Hannover and in Bern led to mobilizations in other German and Swiss cities, like Basel or Köln. Such cases deserve more academic attention, as they suggest that diasporas' mobilizations can be at least partially, if not completely, disarticulated from home/host countries' politics. They also draw our attention towards local, rather than national, processes of mobilization.

Further, it is striking to see that some diaspora sections, whether conflict-generated or not, can become involved in conflicts with which they have no pre-established connection. Global and transnational networks of solidarity with regards to specific conflicts often operate beyond the strict borders of concerned diasporas and, even more interestingly, through other non-directly concerned diasporas. Transnational solidarity movements in favour of the Palestinian cause, or with regards to the situation in Syria, are good examples of such processes (see for instance Hecker 2012). Importantly, this means that diasporas that have not been, even in part, conflict-generated, came become key actors in transnational conflicts. This involvement can be triggered by a shared or similar colonial experience, by the construction of a common historical 'enemy', by cultural factors such as a common religion or language, and so on. These cases seriously question the hermeneutical power of 'origins' or of ethnic labels in the study of the relations between diasporas and conflicts.

Finally, it is worth reiterating how all of these preceding configurations nurture securitization discourses both in countries of origin and in countries of settlement, whereby diasporas are generally represented as potentially dangerous (Sheffer 1994). These discourses are in turn likely to feed processes of fear and withdrawal among diaspora groups, but also 
of reinvestment of traditional identities, thus sometimes becoming self-fulfilling prophecies (Akbarzadeh and Mansouri 2007).

\section{The expanding timespace of diasporas politics}

Obviously, this list of configurations could be further expanded and refined to account for empirical nuances. Nevertheless, it shows how useful it is to move away from perspectives that focus mostly on how diasporas can be 'conflict-generated' and focus instead on the multiple ways diasporas and conflicts can be co-constructed. In addition, envisaging the diaspora-conflict nexus as a series of configurations allows us to study more precisely the role that time and space play both in diasporic identities and in conflict perpetuation, and vice versa. In particular, the above-listed configurations show how the space of conflict can expand through diaspora practices, but also how conflicts incite diasporas to invest new mobilization spheres: through the process of conflict transportation for instance, 'home' conflicts can expand to the territories that diaspora groups inhabit, notably through their practices of territorial segregation. Their expansion could also result from the fact that conflicts can become 'transnationalized', while diaspora groups invest new forms of mobilization, in the cyberspace for instance (Brinkerhoff 2009). In addition, both diasporas and conflicts 'glocalize' each other, as they are simultaneously grounded in a specific location, while building (on) transnational linkages. Crucially, this means that some diaspora groups perform their transnational nature through a direct reference or involvement in one or several conflicts. This allows diasporic identities to be reactivated through an involvement 'over there'; in other words, it is a fundamental mechanism of identity reproduction and maintenance for many diaspora communities. Similarly, the diaspora-conflict nexus affects time. Practices inside diaspora communities can expand conflicts in time, in particular by perpetuating its memory as well as through diasporas' practices of endogamy and other mechanisms of community reproduction, which prolong the effects of conflicts sometimes long after they have ended in countries of origin. Conversely references to protracted conflicts allow the maintenance of diaspora identities in spite of the passing of time. What this entails is that diasporas can be seen as spaces where conflicts can be both expanded and distorted at the same time spatially and temporally. While conflicts can be considered as structuring and mobilizing resources for diasporas, diasporas can conversely constitute reproduction, expansion, and mobilization resources for conflicts. In short, diasporas and conflicts can literally co-construct each other.

\section{Avenues for future research}

In practical terms, unpacking the diaspora-conflict nexus, and studying the above-mentioned configurations while avoiding essentialism, methodological nationalism and teleological fallacy is challenging. It concretely entails to examine at least four sets of issues: actors, discourses, time and space.

First, which actors activate the link between diasporas and conflicts? Actors located in countries of origin, in countries of residence, or among diaspora groups themselves, are obvious targets for analysis. Sending states' diaspora policies such as voting rights or dual citizenship policies, or institutions such as ministries or directorates for diaspora 
affairs, which try to harness diasporas for political and economic purposes, have already generated significant academic interest (see e.g. Gamlen 2008; Ragazzi 2009). Similarly, diaspora organizations or institutions in countries of residence, such as ministries for foreign affairs, play an important role in whether, and how, diaspora mobilize. It is however important to also account for transnational actors and organizations such as Churches, transnational and local cultural organizations, transnational political groups, international media like for instance international TV channels, international businesses, and so on. These actors, which play an instrumental role in the horizontal mobilization of diaspora groups, are also crucial for bypassing the methodological nationalism that still dominates diaspora studies, by allowing us to take the transnational nature of some diaspora mobilizations seriously. Such approach also sheds light on non-violent mobilizations, and small-scale local actors which are often overlooked in analyses focusing on the most visible diaspora actors.

Second, on which discursive articulations is the link between diasporas and conflicts built and strengthened? How are diaspora identities assigned, how are discourses on diaspora produced, on what kind of memories is the link with the home (or another) conflict built? For instance, do diasporas typically refer to ethno-national linkages to trigger mobilization, or are these nationalist tropes sometimes superseded by others, for example referring to human rights, to humanitarian relief, and so on? This notably entails to analyze the types of discourses that diasporas' involvement in conflicts gives birth to, or is the result of, and to pay attention to discourses in which the term diaspora is used in relation to conflict, and for what purposes. Involvement in conflict can function as a way to claim a political status, to affirm oneself as a political actor, and similarly the great popularity of the concept of diaspora among migrant groups suggests that it operates as a way to position oneself as a relevant political actor. Studying how countries of origin, as well as countries of settlement, represent and talk about the link between diasporas and conflicts, and often end up assigning them primary and fixed identities, and securitizing them, is also crucial for challenging stereotypes and essentialism.

Third, what specific temporalities or events activate this link? At the practical level, this entails the study, for instance, of contentious events or time junctures at which the articulation between conflicts and diaspora groups is effected. These events can happen in various settings like the country of origin, the country of settlement, but also at the global level, as the impact of 9/11, of the war in Syria, or of the situation in Palestine, show. It calls for analyzing specific temporalities, notably critical junctures and crises, as initiated by Koinova (2016). For instance, which sections of diaspora communities are more likely to mobilize in phases of conflict escalation or de-escalation, and why are there sometimes discrepancies between conflict sequences, and the timing of mobilizations? The issue of generations, and of generational effects on types of mobilization, like for instance the importance of Internet for younger generations (see the work of Idil Osman 2017), is also of particular importance for understanding whether and how diaspora mobilization is sustained in time.

Finally, in what kind of spaces is the link between diasporas and conflicts activated? Particular attention should be paid to configurations in countries of settlement, including at the micro level (e.g. neighbourhood, communal spaces, everyday spaces of group socialization, etc.), to institutions within the country of origin, but also to transnational forums (e.g. cyberspace, international meetings of civil society organizations, etc.) which might 
appeal to diasporas. Internet in particular has been identified as one of the main locations where conflicts and diasporas meet. The cyberspace facilitates fund raising, but also propaganda activities, and mobilization beyond the strict diasporas' boundaries. Some diasporas' mobilizations exist mostly at the digital level (Brinkerhoff 2009), and Internet has been shown to not only change diasporas' discourses, but also to help them overcome the issue of representation and accountability. In parallel, it has also created cleavages between different sections of the diasporas, between those settled in the neighboring countries and those settled further away, and between those with different educational levels, with more or less easy access to new technologies, as well as between generations. Paying attention to issues of scale, and of spheres of engagement, also means keeping in mind the differences that might arise between the mobilization and involvement of 'contiguous' and 'distant' diasporas (Van Hear and Cohen 2017). Thus, peering more closely at the contentious spaces where diasporas are created, or which diasporas create, is a helpful way to understand if, when and how ethno-national identities are performed in the transnational arena.

\section{Disclosure statement}

No potential conflict of interest was reported by the authors.

\section{Notes on contributors}

Élise Féron is a senior researcher at the Tampere Peace Research Institute (TAPRI), Tampere University. Her research interests include conflict-generated diaspora politics, and gender and conflicts.

Bruno Lefort is an Academy of Finland postdoctoral fellow at the Tampere Peace Research Institute (TAPRI), Tampere University. His research interests include the politics of identification and memory in the Middle East and among diasporic communities.

\section{References}

Adamson, Fiona. 2012. "Constructing the Diaspora. Diaspora Identity Politics and Transnational Social Movements." In Politics from Afar. Transnational Diasporas and Networks, edited by Terrence Lyons and Peter Mandaville, 25-42. New York: Columbia University Press.

Adamson, Fiona. 2013. "Mechanisms of Diaspora Mobilization and the Transnationalization of Civil War." In Transnational Dynamics of Civil War, edited by Jeffrey T. Checkel, 63-88. Cambridge: Cambridge University Press.

Adamson, Fiona, and Madeleine Demetriou. 2007. "Remapping the Boundaries of 'State' and 'National' Identity." European Journal of International Relations 13 (4): 489-526.

Akbarzadeh, Shahram, and Fethi Mansouri, eds. 2007. Islam and Political Violence. Muslim Diaspora and Radicalism in the West. London: Tauris Academic Studies.

Anderson, Benedict. 1993. “The New World Disorder." New Left Review 193: 2-13.

Baser, Bahar. 2015. Diasporas and Homeland Conflicts. A Comparative Perspective. Burlington: Ashgate.

Baser, Bahar, and Ashok Swain. 2008. "Diasporas as Peacemakers: Third Party Mediation in Homeland Conflicts." International Journal on World Peace XXV (3): 7-28.

Bauböck, Rainer. 2008. "Ties Across Borders: The Growing Salience of Transnationalism and Diaspora Politics.” IMISCOE Policy Brief 13: 1-8.

Baubök, Rainer, and Thomas Faist. 2010. "Diaspora and Transnationalism: What Kind of Dance Partners?" In Diaspora and Transnationalism: Concepts, Theory and Methods, edited by Rainer Baubök and Thomas Faist, 9-34. Amsterdam: Amsterdam University Press. 
Bayeh, Jumana. 2015. The Literature of the Lebanese Diaspora. Representation of Place and Transnational Identity. London: IB Tauris.

Beck, Ulrich. 2000. "The Cosmopolitan Perspective: Sociology of the Second Age of Modernity." British Journal of Sociology 51 (1): 79-105.

Bhabha, Homi. 1994. The Location of Culture. London: Routledge.

Brah, Avtar. 1996. Cartographies of Diasporas. Contesting Identities. London: Routledge.

Brinkerhoff, Jennifer. 2009. Digital Diasporas, Identity and Transnational Engagement. Cambridge: Cambridge University Press.

Brubaker, Rogers. 2005. “The 'Diaspora' Diaspora.” Ethnic and Racial Studies 28 (1): 1-19.

Brubaker, Rogers, and Frederik Cooper. 2000. "Beyond 'Identity." Theory and Society 29: 1-47.

Bruneau, Michel. 2010. "Diasporas, Transnational Spaces and Communities." In Diaspora and Transnationalism: Concepts, Theory and Methods, edited by Rainer Baubök and Thomas Faist, 35-49. Amsterdam: Amsterdam University Press.

Butler, Kim. 2001. "Defining Diaspora, Refining a Discourse." Diaspora: A Journal of Transnational Studies 10 (2): 189-219.

Canefe, Nergis. 2002. "Markers of Turkish Cypriot History in the Diaspora: Power, Visibility and Identity." Rethinking History 6 (1): 57-76.

Chivallon, Christine, and Denis-Constant Martin. 2006. "Une culture contre le politique? Des sociétés afro-américaine face au politique." In Les diasporas dans le monde contemporain, edited by William Berthomere and Christine Chivallon, 339-346. Paris-Pessac: Karthala-MSHA.

Cochrane, Feargal, Bahar Baser, and Ashok Swain. 2009. "Home Thoughts from Abroad: Diasporas and Peace-building in Northern Ireland and Sri Lanka." Studies in Conflict and Terrorism 32 (8): 681-704.

Collier, Paul, and Anke Hoeffler. 2000. Greed and Grievance in Civil war. Washington, DC: World Bank Development Research Group.

Dayal, Samir. 1996. "Diaspora and Double Consciousness." The Journal of the Midwest Modern Language Association 29 (1): 46-62.

Demmers, Jolle. 2007. "New Wars and Diasporas: Suggestions for Research and Policy." Journal of Peace, Conflict and Development 11: 1-26.

Féron, Élise. 2013. "Diaspora Politics: From Long Distance Nationalism to Autonomization." In Migration and Organized Civil Society: Rethinking National Policy, edited by Dirk Halm and Zeynep Segin, 63-79. New York: Routledge.

Féron, Élise. 2014. "Stating the Obvious? The Role of Diaspora and Migrant Organizations in Development." In The Strength of Culture for Development; Why Culture Matters in International Cooperation, edited by Pascaline Gaborit, 81-99. Brussels: Peter Lang.

Féron, Élise. 2017. “Transporting and Re-inventing Conflicts: Conflict-generated Diasporas and Conflict Autonomisation." Cooperation and Conflict 52 (3): 360-376.

Gamlen, Alan. 2008. "The Emigration State and the Modern Geopolitical Imagination.” Political Geography 27: 840-856.

Glick Schiller, Nina. 2005. "Blood and Belonging: Long Distance Nationalism and the World Beyond.” In Complexities Beyond Nature and Nurture, edited by Susan McKinnon and Sydel Silverman, 290-312. Chicago: Chicago University Press.

Glick Schiller, Nina. 2009. "A Global Perspective on Transnational Migration: Theorizing Migration without Methodological Nationalism." Centre on Migration, Policy and Society, Working Paper no. 67.

Glick Schiller, Nina. 2013. "The Transnational Migration and Paradigm: Global Perspectives on Migration Research.” In Migration and Organized Civil Society: Rethinking National Policy, edited by Dirk Halm and Zeynep Segin, 25-44. New York: Routledge.

Hall, Stuart. 1994. "Cultural Identity and Diaspora." In Colonial Discourse and Post-colonial Theory: A Reader, edited by Patrick Williams and Laura Chrisman, 222-237. New York: Columbia University Press.

Hall, Stuart. 1995. "New Cultures from Old." In A Place in the World? Places, Cultures and Globalization, edited by Massey Jess, Pat Jess, and Doreen Massey, 175-214. Oxford: Oxford University Press. 
Hannerz, Ulf. 1996. Transnational Connections: Culture, People, Places. London: Routledge. Hecker, Marc. 2012. Intifada Française, De l'importation du conflit israélo-palestinien. Paris: Ellipses. Hepner, Tricia Redeker. 2009. "Generation Nationalism and Generation Asylum: Eritrean Migrants, the Global Diaspora, and the Transnational Nation-state." Diaspora 18 (1/2): 184-207.

Horst, Cindy. 2008. "The Transnational Political Engagements of Refugees: Remittance Sending Practices amongst Somalis in Norway, Conflict." Security and Development 8 (3): 31-339.

Horst, Cindy, et al. 2010. "Participation of Diasporas in Peacebuilding and Development." PRIO Report. A Handbook for Practitioners and Policymakers, Oslo, February.

Humphrey, Michael. 1998. Islam, Multiculturalism, and Transnationalism from the Lebanese Diaspora. London: IB Tauris.

Israel, Nico. 2000. Outlandish: Writing Between Exile and Diaspora. Stanford: Stanford University Press.

Knock, Kim, and Sean McLoughlin. 2010. "Introduction.” In Diasporas - Concepts, Intersections, Identities, 1-16. London: Zed Books.

Koinova, Maria. 2011. "Diasporas and Secessionist Conflicts: The Mobilization of the Armenian, Albanian and Chechen Diasporas." Ethnic and Racial Studies 34 (2): 333-356.

Koinova, Maria. 2016. "Sustained vs Episodic Mobilization among Conflict-generated Diasporas." International Political Science Review 37 (4): 500-516.

Koinova, Maria. ed. 2018. "Diaspora Mobilization for Conflict and Postconflict Reconstruction: Contextual and Comparative Dimensions." Journal of Ethnic and Migration Studies 44 (8).

Latour, Bruno. 2004. Politics of Nature: How to Bring the Sciences Into Democracy. Cambridge: Harvard University Press.

Lucassen, Leo. 2005. The Immigrant Threat: The Integration of Old and New Migrants in Western Europe Since 1850. Chicago: University of Illinois Press.

Lyons, Terrence. 2007. "Conflict-generated Diasporas and Transnational Politics in Ethiopia." Conflict, Security and Development 7 (4): 529-549.

Ma Mung, Emmanuel. 2007. "Conclusion générale: Les vêtements neufs de la diaspora, digression sur les paradoxes diasporiques." In Les diasporas dans le monde contemporain, edited by William Berthomere and Christine Chivallon, 409-415. Paris-Pessac: Karthala-MSHA.

Moliner, Christine. 2007. "Frères ennemis? Relations between Panjabi Sikhs and Muslims in the Diaspora." South Asia Multidisciplinary Academic Journal 1. http://samaj.revues.org/135.

Osman, Idil. 2017. Media, Diaspora and the Somali Conflict. London: Palgrave Macmillan.

Østergaard-Nielsen, Eva. 2006. Diasporas and Conflict Resolution - Part of the Problem or Part of the Solution? Copenhagen: Danish Institute for International Studies Brief.

Østergaard-Nielsen, Eva. 2012. "Politcal Liberalization and Contestation of Transnational Relations Between Morocco and Moroccan Migrants in Spain.” In Politics from Afar. Transnational Diasporas and Networks, edited by Terrence Lyons and Peter Mandaville, 69-87. New York: Columbia University Press.

Ragazzi, Francesco. 2009. “Governing Diasporas.” International Political Sociology 3: 378-397.

Safran, Wiliam. 1991. "Diasporas in Modern Societies: Myths of Homeland and Return." Diaspora: A Journal of Transnational Studies 1 (1): 83-99.

Shain, Yossi, and Aharon Barth. 2003. "Diasporas and International Relations Theory." International Organization 57 (3): 449-479.

Sheffer, Gabriel. 1994. "Ethno-National Diasporas and Security." Survival 36 (1): 60-79.

Shiva, Vandana. 1988. "Reductionist Science as Epistemological Violence." In Science, Hegemony and Violence, edited by A. Nandy, 232-256. Delhi: Oxford University Press.

Smith, Hazel, and Paul Stares. 2007. Diasporas in Conflict: Peace Makers or Peace Wreckers? Tokyo: United Nations University Press.

Spivak, Gayatri. 1990. The Post-colonial Critic: Interviews, Strategies, Dialogues. New York: Routledge.

Van Bruinessen, Martin. 1998. "Shifting National and Ethnic Identities: The Kurds in Turkey and the European Diaspora." Journal of Muslim Minority Affairs 18 (1): 39-52.

Van Hear, Nicholas, and Robin Cohen. 2017. "Diasporas and Conflict: Distance, Contiguity and Spheres of Engagement.” Oxford Development Studies 45 (2): 171-184. 
Vertovec, Steven. 1997. “Three Meanings of 'Diaspora', Exemplified among South Asian Religions.” Diaspora: A Journal of Transnational Studies 6 (3): 277-299.

Vertovec, Steven. 2010. “Cosmopolitanism." In Diasporas - Concepts, Intersections, Identities, edited by Kim Knock and Sean McLoughlin, 1-16. London: Zed Books.

Werbner, Pnina. 2002. "The Place Which is Diaspora: Citizenship, Religion and Gender in the Making of Chaordic Transnationalism." Journal of Ethnic and Migration Studies 28 (1): 119-133. Wimmer, Andreas, and Nina Glick Schiller. 2002. "Methodological Nationalism and Beyond: Nation-state Building, Migration and the Social Sciences.” Global Networks 2 (4): 301-334. 